\title{
ARTICLES
}

\section{Evolving Concepts of Self- Determination and Autonomy in International Law: The Legal Status of Tibet}

\section{Valerie Epps*}

\begin{abstract}
This article traces the evolution of the concept of self-determination from the end of World War I, through the era of decolonization, to the present day when it has become embedded in the human rights framework and, in limited circumstances, is used to justify secession. Various national and international cases are examined in analyzing the jurisprudence of self-determination, as well as the new European standards for State recognition after secession. The concept of autonomy is also examined as possibly providing a solution for disaffected minority groups within a greater territorial unit. The article then applies the self-determination and autonomy frameworks to Tibet and examines possible solutions for assessing Tibet's international status.
\end{abstract}

\section{Introduction: Scope of the Article}

Open any serious newspaper and before too long you will find a story about a separatist movement, often accompanied with details of bombings and the number of dead or injured. These separatist uprisings, not always involving armed conflict, span the globe from South Ossetia and Abkhazia in Georgia, to Indian administered Kashmir; from the

* B.A.(Birmingham); J.D.(Boston); LL.M.(Harvard). Professor of Law and Director of the International Law Concentration, Suffolk University Law School, Boston. U.S.A. Professor Epps was a Visiting Professor at Hongik University College of Law, Seoul, Korea in 2008 and a Distinguished Fulbright Lecturer at Fudan University, Shanghai, China in 2006. 
Basque region of Spain, to Scotland in the United Kingdom; from Quebec in Canada, to Chechnya in Russia; from the Uighur region of Xinjiang Province in China, to Somaliland in Somalia, Africa. Most of these claims for more autonomy or secession fester for a long period of time, and usually, although not always, arise out of some sense of injustice by the ruling group of the larger state towards the separatist area. Separation sometimes occurs peacefully, such as the separation of the Czech Republic and Slovakia in 1993, but more often the claims either fade into obscurity or result in a bloody civil war.

War sometimes brings success for the separatists, in the sense of gaining independence from a larger territorial state, although at great cost, both human and material, such as in Eritrea which gained independence from Ethiopia in 1993, and East Timor which became independent from Indonesia in 2002. Sometimes the separatists are not successful, such as in Biafra which declared independence from Nigeria in 1967 but was reabsorbed into Nigeria after much bloodshed in 1970. Sometimes areas claiming separation operate for many years as virtually independent entities but are not recognized as a state by other states (or only a handful of states) such as NagornoKarabakh inside Azerbaijan or Transnistria inside Moldova. This article will examine the status of secession and autonomy claims in international law and will suggest applications of that law to Tibet.

\section{Secession as a Legal Concept}

The late Professor Hersch Lauterpacht took the view that: "International law does not condemn rebellion or secession aiming at the acquisition of independence."1 This view is reiterated by Professor James Crawford in his comments on certain Security Council resolutions which he determined took the view that "secession is neither legal nor illegal in international law, but a legally neutral act the consequences of which are regulated internationally."2

Claims of secession, standing alone, that is, based on nothing more than a wish to separate from the larger state, find no legitimacy within international law ${ }^{3}$ but the term

\footnotetext{
HeRsch LaUterPaCHt, RECOGNITION IN INTERNATIONAL LAW 8 (1947).

James Crawford, The Creation of States in International Law 390 (Oxford 2nd. ed. 2006).

Of course, secession based simply on the desire to separate from a larger entity does occur but the separation is effected through political negotiation and settlement, not as a right under international law. See e.g. the Karlstad Agreement (1905) under which Norway and Sweden agreed to become separate nations. Act between Norway and Sweden relative to the Dissolution of the Union, Clive Parry, 199 The ConsoldDATED
} 
has burrowed its way into part of the concept of self-determination and has thereby gained a form of legitimacy in international law in certain limited circumstances. The secession aspect of self-determination still haunts the borders of an evolving legal concept, or an expression of political will or human aspiration. The concept never quite settles down into a black letter law precept, but it is never fully relegated to simply the cry of the disenchanted. The amorphous nature of self-determination makes it both fascinating and frustrating. Self-determination in its secessionist mode always challenges one of the bed-rock concepts of modern international law, namely the territorial integrity of the sovereign state. 4

\section{A. The Evolution of the Meaning of Self-Determination}

\section{The League of Nations}

The term, "self-determination" has undergone considerable historical transmutation since it was tossed into the international arena by U.S. President Woodrow Wilson after World War I, when the victorious powers were busy carving up the rubble of the Austro-Hungarian and Ottoman Empires. ${ }^{5}$ There is a certain irony to the use of this phrase as this was a time when victorious states expected to, and certainly did, redistribute conquered lands after warfare with no regard for the wishes of the residents. Nonetheless, the phrase and the concept gained traction.

The Covenant of the League of Nations did not mention self-determination, although the Mandate System was charged with ensuring that: "the principle that the well-being and development of such peoples [i.e. peoples within the area to be governed by the Mandatory Power] form a sacred trust...." 6 The idea of asking for the consent of the people within the Mandatory territories was simply never considered. The Commission of Jurists firmly rejected the notion of a right to separation from the larger governing entity in its decision on the status of the Aaland Islands in 1920, even though the inhabitants overwhelming wished to separate from Finland and re-unite

TREATY SERIES 1648-1919, 191 (1969-1981).

4 See e.g. U.N. Charter art. 2(4). G.A. Res., 1514; U.N. GAOR, 15th Sess., Supp. No. 16, at 67; U.N. Doc. A/L323 and Add. 1-6 (1960); G.A. Res. 2625, U.N. GAOR, 25th Sess., 1883d plen. mtg., Supp. No. 28, at 121, U.N.Doc. $\mathrm{A} / 8028$, at 124 (1970).

5 President Wilson stated: "National aspirations must be respected; peoples may now be dominated and governed only by their own consent. Self-determination is not a mere phrase. It is an imperative principle of action, which statesmen will henceforth ignore at their peril." War Aims of Germany and Austria, in 3 THE Public Papers of Woodrow Wilson: War and Peace 177 (Ray Stannard Baker \& William E. Dodds eds. 1927).

6 Covenant of the League of Nations art. 22 (1919-1924). 
with Sweden.7 "Positive International Law does not recognize the right of national groups, as such, to separate themselves from the State of which they form a part by the simple expression of a wish, anymore than it recognizes the right of other States to claim such a separation."8

\section{The United Nations Charter}

The United Nations Charter twice mentions "self-determination." Article one, paragraph 2 states that a purpose of the U.N. is: "to develop friendly relations among nations based on respect for the principle of equal rights and self-determination of peoples...."9 Article 55 notes that "peaceful and friendly relations among nations" should be "based on respect for the principle of equal rights and self-determination of peoples...."10 The linguistic dissonance between the idea of promoting peace "among nations" (emphasis added) but, at the same time, calling for "self-determination of peoples" (emphasis added) was understood, at the time, as simply a reference to the self-determination of the inhabitants of the dependent territories of the League's Mandate system in the context of transferring them to the new U.N. Trusteeship system. This new system included the areas being administered under a Mandate and other non-self-governing territories either "detached from enemy states as a result of the Second World War"11 or "voluntarily placed under the [Trusteeship] system...."12

The Charter did, however, have rather more instructions on the purposes guiding the Trusteeship system than the League's Covenant. Article 73 of the Charter indicates that the administering power must "develop self-government, ... take due account of the political aspirations of the peoples, and ... assist them in the progressive development of their free political institutions ...."13 Article 76 goes further and speaks of promoting "self-government or independence" but then adds "as may be appropriate to the particular circumstances of each territory and its peoples and the freely expressed wishes of the peoples concerned...."14 The language of the Charter accepts an

7 From the thirteenth century the Aaland Islands and Finland were part of the Kingdom of Sweden. In 1809 Sweden ceded Finland and the Islands to Russia. From 1917, the Aaland Islands sought to reunite with Sweden but the Commission of Jurists decided they had to remain part of Finland but should be granted considerable autonomy.

8 Report of the International Committee of Jurists upon the Legal Aspects of the Aaland Islands Question, League of Nations, O.J. Spec. Supp. 3, at 5 (1920). See Encyclopedia BritanniCa(2008), available at http://www.britannica.com/EBchecked/topic/12162/Aland-Islands

9 U.N. Charter art 1(2).

$10 \quad$ Id. at art. 55.

11 U.N. Charter art. 77(1)(b).

$12 I d$. at 1(c).

13 U.N. Charter art. 73(b).

14 Id. at art. 76(b). 
essentially colonial system but self-government, and even independence of the Trust administered territories, is clearly the ultimate aim, admittedly at some future, undetermined date, and only when the Trustee decides that the peoples of the territory have reached a stage of advancement warranting such a transfer of power. The notion of sections of a particular trust territory (or indeed sections of an existing state) getting the right to sever themselves from the larger territory was not considered an option.

\section{Decolonization}

Decolonization linked self-determination to the right to political participation in governance. The General Assembly became very active in the movement towards granting independence to colonial territories. In 1960, the General Assembly declared that "All peoples have the right to self-determination; by virtue of that right they freely determine their political status and freely pursue their economic, social and cultural development."15 This broad declaration, named the "Declaration on the Granting of Independence to Colonial Countries and Peoples" concludes, however, as many similar declarations, with a prohibition against reading the right of self-determination as a right of secession: "Any attempt aimed at the partial or total disruption of the national unity and the territorial integrity of a country is incompatible with the purposes and principles of the Charter of the United Nation."16

\section{Uti Possidetis}

Another principle of international law that works hand-in-hand with decolonization and against the fracturing of territories through partial cesession is the principle of $u t i$ possidetis (as you did possess, so you shall possess), under which colonial territories claiming independence must accept their territorial boundaries as they were drawn and administered by the colonial power. This paradoxical principle, which simultaneously casts off colonialism but insists on the acceptance of one of the most powerful manifestations of colonial power, namely the determination of borders, has been reaffirmed by the International Court of Justice in a number of cases involving territorial disputes. 17 The Court seems to have accepted this principle in part because it has been

15 G.A. Res. 1514, U.N. GAOR, 15th Sess., Supp. No. 16, at 67, U.N. Doc. A/L 323 and Add. 1-6 (1960).

16 Id. at 4. See also Declaration on Principles of International Law Concerning Friendly Relations and Cooperation among States in accordance with the U.N. Charter, G.A. Res. 2625; U.N. GAOR, 25th Sess., 1883rd plen. mtg., Supp. No. 28, at 121; U.N. Doc. A/8028, at 124 (1970).

17 See e.g. Frontier Dispute (Burk. Faso v. Mali), 1986 I.C.J. 554 (Dec. 22); Land, Island and Martime Frontier Dispute (El Sal. v. Hond.), 1992 I.C.J. 351 (Sept. 11). 
accepted by many states that had been under colonial rule18 and in part "to prevent the independence and stability of new States being endangered by fratricidal struggles provoked by the challenging of frontiers following the withdrawal of the administering power."19 Some scholars regard the rule of uti possidetis as directly conflicting with the right of self-determination and have argued that "the rule has often given rise to ethnic conflicts and may in fact be one of the main exacerbators of civil wars." 20

Dismantling the colonial system did not dismantle the idea of the state and the need for territorial integrity, rather it enunciated a norm of self-government within preexisting colonial boundaries. Self-government began to be seen in terms of a right attaching to persons to participate in their own governance and not to be ruled by foreigners. Professor Thomas Franck, in his seminal article The Emerging Right to Democratic Governance, notes that: "Self-determination postulates the right of a people organized in an established territory to determine its collective political destiny in a democratic fashion...."21

The idea of rights attaching to persons, or groups of persons, has seen exponential growth since the middle of the twentieth century when the modern human rights movement began its remarkable progress. The movement had earlier antecedents in the French Enlightenment and various national bills of rights but it was not until the latter part of the twentieth century that the idea of human rights as an established part of the international legal framework was accepted.22

See e.g. Cairo Declaration of 1964, OAU Cairo Declaration on Border Disputes Among African States, available at http://africa-union.org/root/au/Documents/Decisions/hog/bttoGAssembly1964.pdf.

19 Frontier Dispute, supra note 17, at 23.

20 Valerie Epps, International LaW 45 (3d ed. 2005) citing Joshua Castellino \& Steve Allen, Title to Territory in International LaW A Temporal Analysis, Ch. 1 (2003). The rule has also been applied in the European context. See e.g. Statement of the European Arbitration Commission Relating to the Break Up of the Former Yugoslavia, 92 I.L.R. 168 (1992).

21 Thomas Franck, the Emerging Right to Democratic Governance, 86 Am. J. INT'L L. 46, 52 (1992).

22 Although a number of states, notably China, continue to challenge the theory of human rights as based on Western ideas of the individual's relationship with the community, China now issues its own human rights reports and regularly criticizes the U.S. for failure to live up to certain norms that are drawn directly from the broadly accepted catalogue of human rights. See e.g. China Report Attacks U.S. Human Rights Record as "Tattered and Shocking," International Herald Tribune (Mar. 13, 2008), available at http://www.iht.com/articles/ap/2008/03/13/asia/AS-GEN-China-US-Human-Rights.php (last visited on Oct. 1, 2008). The Chinese report has been issued annually since 1998 by the Information Office of the State Council of the People's Republic of China. For the full text of the 2007 Chinese Report, available at http://asiaing.com/human-rights-record-of-united-states-in-2007.html (last visited on Oct. 1, 2008). 


\section{The Human Rights Framework: Self-Determination and Secession}

\section{A. The Principal Covenants and Self-Determination}

Self-determination as a right is mentioned in both the International Covenant on Civil and Political Rights 23 and the International Covenant on Economic Social and Cultural Rights. 24 Both Covenants declare: "All peoples have the right of self-determination. By virtue of that right the freely determine their political status and freely pursue their economic, social and cultural development." Once we moved beyond the context of the mandates and colonies, and beyond what type of government is required, we are left with two questions: firstly, who are these peoples to whom this right attaches?; and secondly, does this right include a right of secession, and, if so, when?

\section{B. The Peoples or The Self to Whom Self-Determination Attaches}

Who are the peoples who are stated to have rights to self-determination.? Presumably, at least in the colonial context, they are the residents of the colonial territory. The more difficult question is whether the term peoples can refer to a sub-group of the whole body of an existing state's citizenry. There has been much scholarship suggesting that certain distinct groups, defined by such things as race, ethnicity, culture, religion, language, history and tradition, can define what is meant by people. The 1993 Vienna Declaration, which arose out of the U.N. World Conference on Human Rights, emphasized that there should be no distinction between people of "any kind." 25 The prohibition on distinctions arose out of the right of peoples to pursue their own political status. States were informed that they had "a duty to respect this right...." 26 but, the Declaration still rejected dismemberment of territorial integrity. Nonetheless, it went on to say that governments must "represent the whole people belonging to the territory...."27 The various Declarations grant a right of self-determination to people and place obligations on states to respect this right so that the state's government

\footnotetext{
23 Art. 1, 999 U.N.T.S. 171. G.A. Res. 2200; 21 GAOR, Supp. 16; U.N. Doc. A1 6316, at 52, entered into force Mar. 23, 1976.

24 Art. 1, 993 U.N.T.S. 3, Annex to G.A. Res. 2200; 21 GAOR, Supp. 16; U.N. Doc. A/6316 at 490, entered into force Jan. 3, 1976.

25 Vienna Declaration and Programme of Acton, U.N. Doc. A/Conf. 157/24 (pt.I) at art. 2, para 3 (1993).

26 G.A. Res. 2625. See supra note 16, at 123-124.

27 Id. at 124 .
} 
represents the whole of the people without any distinctions. What the Declarations do not describe is what right (or remedies) accrue to the unrepresented people if a state does not have a government representing the whole people. This is where the so-called right to secession comes in. The argument is that if people have a right to self-determination, and if a state has an obligation to ensure the establishment of a government that represents the whole people, then if the state has failed in its obligation, the prohibition on secession disappears and any sub-set of the people that can credibly claim nonrepresentation, can then secede in order to ensure their own self-determination. This jump, from the failure to fulfill an obligation to the creation of the remedy for such a failure, remains highly controversial but, in many ways, it is what drives every established state's recognition of independence when claimed by a part of a larger preexisting state, whether some European state's recognition of Kosovo28 or Russian recognition of Abkhazia and South Ossetia.29

\section{Court Cases Discussing Self-Determination or Secession}

\section{A. A National Court Decision}

The Supreme Court of Canada was asked for an advisory opinion on whether the province of Quebec had the right to secede from Canada either under Canadian law or under international law. In the circumstances of the case, it answered "No" to both questions but in doing so it assessed the state of international law on the subject. 30 The Court came to the conclusion that generally the right of self-determination must be exercised within the framework of the state structure. This notion the Court called

28 In February of 2008, the European Union could not reach agreement as a whole on the recognition of Kosovo so each member nation made the decision independently. Germany, Britain, France and Italy issued early recognition statements, available at http://www.voanews.com/english/archive/2008-02/2008-02-18-voa49.cfm? As of Oct. 8, 2008, twenty-two EU members had recognized Kosovo's independence making a total of 48 recogntions. FinANCIAL Times, Oct. 8, 2008, available at http://www.ft.com/cm/s/o/040b1848-9567-11dd-aedd000077607658.htm?nclick_check=1 (last visited on Oct. 8, 2008). On Oct. 8, 2008, the U.N. General Assembly requested an advisory opinion from the I.C.J. on the following question: "Is the unilateral declaration of independence by the Provisional Institutions of Self-Government of Kosovo in accordance with international law?" G.A. Res. 1076; U.N. GAOR, 63rd Sess.; U.N. Doc. A/RES/63/3 (Oct. 8, 2008).

29 Russia formally recognized the independence of Abkhazia and South Ossetia, territorially located in Georgia, on Aug. 26, 2008, see GLOBAL VoICES, available at http://globalvoicesonline.org/2008/26/russia-gerogiaunilateral-recongition-of-abkhaziaandsouthossetias-independence(last visited on Oct. 8, 2008).

30 Reference re Secession of Quebec, 2 CAN. S.C.R. 217 (1998). 
"internal self-determination." 31 Nonetheless, the Court noted that "a people" may be interpreted to include "only a portion of the population of an existing state." 32 It also recognized that in "exceptional circumstances a right of secession may arise."33 Such a right "arises in only the most extreme of cases and, even then, under carefully defined circumstances." 34 The Court listed three examples of extreme cases. Firstly, the right of colonial peoples to declare independence was considered undisputed.35 Secondly, where, outside the colonial context, a people "is subject to alien subjugation, domination or exploitation" there was a right to secede. ${ }^{36}$ This situation the Court also believed to be settled law. Thirdly, "when a people is blocked from the meaningful exercise of its right to self-determination internally, it is entitled, as a last resort, to exercise it by secession...."37 The Court conceded that this last circumstance was not yet "an established international law standard."38 Although the Court was clear that none of these extreme circumstances applied to Quebec, it went on to discuss what it called "The Effectively Principle."39 This principle, operative in all law, describes the way that law, usually, adapts to political reality. The Court recognized that if Quebec did declare independence and if, over time, the international community broadly recognized it as an independent state, then, at some point, the law would rearrange itself to recognize the new state even though the secession originally came about illegally.40

\section{B. International Court Decisions}

A number of the International Court of Justice's decisions discuss self-determination. In the 2004 Advisory Opinion on the Legal Consequences of the Construction of a Wall in the Occupied Palestinian Territories 41 the Court references a number of General Assembly Resolutions in the context of the Palestinian territories, 42 and notes that the principle of "self-determination of peoples has been enshrined in the United Nations Charter and reaffirmed by the General Assembly in resolution $2625(\mathrm{XXV}) \ldots . . " 43$ It also notes that

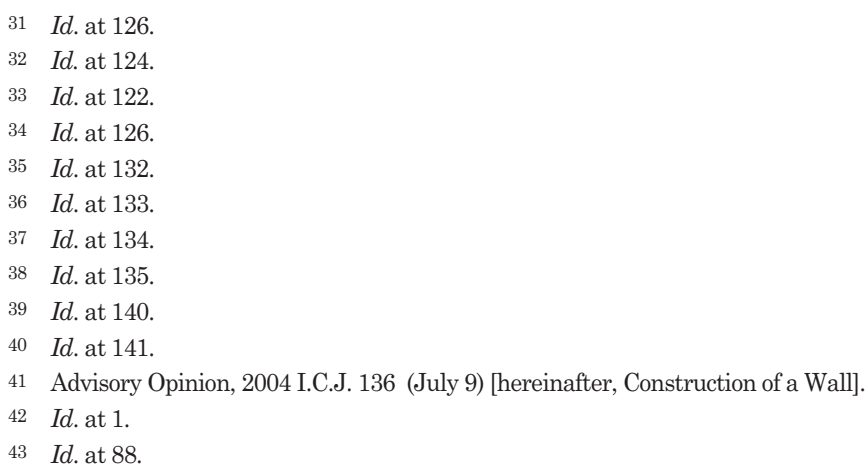


States have "the duty to refrain from any forcible action which deprives peoples ... of their right to self-determination." 44 The Court had previously emphasized that the principle of self-determination applies to all non-self-governing territories. 45 It also declared that "the existence of a 'Palestinian people' is no long in issue," 46 having been recognized as such by Israel. Ultimately, the Court declared that the right of selfdetermination was a legitimate right of the Palestinians 47 and that the location of the particular route of the wall, some of it on Palestinian territory, being constructed by Israel "severely impedes the exercise by the Palestinian people of its right to selfdetermination...." 48 This right is described as a right erga omnes.49 Judge Higgins, in her separate opinion, alluded to the "substantial body of doctrine and practice on 'selfdetermination beyond colonialism',"50 quoting several General Assembly resolutions. In this case then, the Court recognizes a right of self-determination as attaching to a people who do not yet constitute a state when they are under alien occupation.

In the East Timor 51 case, the Court discussed the issue of self-determination for the people of East Timor, then a non-self governing territory 52 but ultimately dismissed the case on jurisdictional grounds. Nonetheless, self-determination was described as having "an erga omnes character" 53 and being "one of the essential principles of contemporary international law. 54 Judge Weeramantry, in his dissenting opinion, engages in a comprehensive description of the development of self-determination within the United Nations 55 which he also links to the principle of permanent sovereignty over natural resources. ${ }^{56}$ Judge ad hoc Skubiszewski, in his dissenting opinion, notes the link that some jurists have made between self-determination and "the principle of inviolability of borders." 57

44 Id.

45 Legal Consequences for States of the Continued Presence of South Africa in Namibia (South West Africa) notwithstanding Security Council Resolution 276 (1970), Advisory Opinion, 1971 I.C.J. 31 (Jun. 21) at 52-53.

46 Construction of a Wall at 118.

47 Id.

48 Id. at 122 .

49 Id. at 155. See also East Timor (Port v. Austl.) 1995 I.C.J. 102 (Jun. 30) at 29.

50 Construction of a Wall, at 29 (separate opinion of Judge Higgins).

51 East Timor (Port v. Austl.) 1995 I.C.J. 102 (Jun. 30).

52 Id. at 29 \& 31. East Timor became a Portuguese colony in the sixteenth century. In 1975 it declared independence but was invaded by Indonesia which continued in occupation until 1999. After a U.N. sponsored referendum, the country became an independent state in 2002, known as The Democratic Republic of Timor-Leste.

$53 \quad I d$. at 29.

54 Id.

55 Id. at 193-197 (dissenting opinion of Judge Weeramantry).

56 Id. at 197-200. Judge Weeramantry also discusses the duties for other members of the international community that spring from the right to self-determination. Id. at 205-216.

57 Id. at 135 quoting, Keiba Mbaye, Introduction to Part Four, Human Rights and Rights of Peoples, in 
In the Western Sahara case, 58 the Court, in a decolonization context, was grappling with claims by a number of states to the territory of the Western Sahara on the basis of alleged "legal ties" as well as the right of self-determination on the part of the people of the Western Sahara. The Court reiterated that the principle of self-determination applies to all non-self-governing territories.59 It cited General Assembly resolutions $1514($ XV)60 and 2625 (XXV)61 and affirmed "the need to pay regard to the freely expressed will of peoples...." 62 in the decolonization process. Judge Petrén, in his separate opinion, berates the Court for failing to answer "the question of the balance which has to be struck between the right of [a colony's] population to self-determination and the territorial integrity of one or even several States." 63

In its Advisory Opinion on Namibia (South West Africa), 64 the International Court of Justice narrates the gradual development of the principle of self-determination from the League's Mandate system to the United Nation's Trusteeship system and declared that the principle "clearly embraced territories under a colonial regime.... [and later] all peoples and territories which 'have not yet attained independence'. "65 "[T]he ultimate objective of the sacred trust [of the Mandate system] was the self-determination and independence of the peoples concerned."66 Judge Zafrulla Khan, in a separate declaration, rejected " 'some kind of autonomy and local self-government [for Namibia] within a larger arrangement of co-operation' [as suggested by the South African representative] ...[which Judge Khan determined] in effect means a denial of selfdetermination as envisaged in the Charter of the United Nations."67 He understood self-determination, in this context, to be nothing less than independence. Judge Onyeama noted that annexation of a mandated territory by the Mandatory Power would also be a denial of the "sacred trust" of the Mandate system. 68 Judge Padilla Nervo examined the statements made at the Versailles Peace Conference after WWI which had rejected the annexation of South West Africa. He declared: "The avowed annexation was then and is now improper and unacceptable."69 This advisory opinion

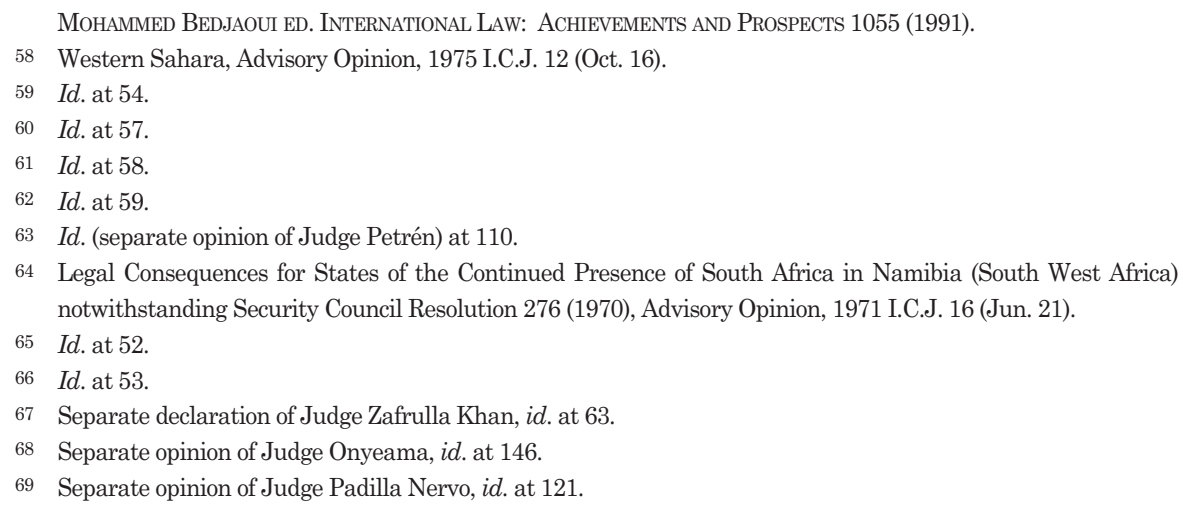


is clear in its jurisprudence that self-determination means self-government and independence in the Mandate/Trusteeship system and forbids absorption or annexation by the Mandatory Power.

In the Preliminary Objections judgment of the Punishment of the Crime of Genocide Case,70 the Federal Republic of Yugoslavia (FRY) argued that the seceding entity of Bosnia-Herzegovina "was not...qualified to become a party to the [Genocide] convention."71 The FRY believed that by this act of secession from Yugoslavia, BosniaHerzegovina had "flagrantly violated the duties stemming from the 'principle of equal rights and self-determination of peoples.' "72 In other words, the FRY was arguing that secession was not part of the right to self-determination. The Court, however, simply noted that Bosnia-Herzegovina had become a member of the U.N. by decisions of the General Assembly and Security Council in 199273 and this did not discuss the issue of the legitimacy of secession or whether such an act went beyond what is encompassed by self-determination.

Looking at the Court's decisions as a whole, there is almost no discussion of secession or the fracturing of pre-existing boundaries. The cases discussing selfdetermination arise in the circumstances of foreign occupation, or progression from being a colony to achieving independence, or from a Mandatory territory to a state under the U.N. Trusteeship system. All of the cases are tinged with talk of selfgovernment and independence but only within pre-existing borders and only as part of the process of emerging from being a non-self-governing territory to gaining full independence.

The Court has yet to address the issue of secession by part of a state from a larger territorial entity, but this opportunity has recently arisen in the context of Kosovo's declaration of independence from Serbia. On October 8, 2008, the General Assembly of the United Nations adopted a resolution drafted by Serbia requesting an advisory opinion from the International Court of Justice on the following question: "Is the unilateral declaration of independence by the Provisional Institutions of SelfGovernment of Kosovo in accordance with international law?"74 The vote was heavily divided with 77 in favour, 6 against, 74 abstentions and 28 states absent. The geographic spread of the vote was remarkable. Those who voted in favour included states from Asia, Africa, South America, Europe and the Middle East, including the

Application of the Convention on the Prevention and Punishment of the Crime of Genocide (Bosn. - Herz. v. Yugo.), 1996 I.C.J. 595 (Preliminary Objections, Judgment of July 11).

71 Id. at 611.

72 Id.

73 Id.

74 G.A. Res. 10764; U.N. GAOR, 63rd Sess.; U.N. Doc. A/RES/63/3 (Oct. 8, 2008). 
Democratic Peoples Republic of Korea. The six who voted against were Albania, Marshall Islands, Micronesia, Nauru, Palau and the United States. No doubt the U.S. tried hard to persuade other states to vote with her against the resolution. Her obvious lack of success may be as significant as array of those who abstained who, again, stretched from Australia to Europe, from Africa to the Middle East and Asia, including the Republic of Korea.

The Foreign Minister of Serbia, Vuk Jeremić, who introduced the resolution sought to assure the General Assembly that an advisory opinion "would provide politically neutral and judicially authorative guidance to many countries still deliberating how to approach such unilateral declarations of independence in line with international law."75

A number of states made declarations about their votes. Ruth Marie Di Carlo stated that the United States thought that the request for an advisory opinion was "unnecessary and unhelpful,"76 although she assured U.N. members that the U.S. would work with Serbia "to advance peace in the region."77 Sir John Sawers for the United Kingdom, who abstained, indicated that the U.K. regarded the request as "motivated primarily for political - rather than legal-reasons...."78 He stated that "Kosovo's independence is, and will remain, a reality."79 Albania thought the request "manipulative." 80 Mexico indicated that she regarded the request as "a peaceful means of settling disputes."81 Egypt stated that the request presented "a legal issue, not a political question." 82 Indonesia reminded members that the U.N. Charter "allowed the Court to give an advisory opinion on any [legal] issue." 83

The wide range of declarations given in explanation of votes on the request for the advisory opinion, ensure that the I.C.J. will, in all probability, address the propriety of issuing an advisory opinion on the question posed. Since its establishment, the Court has issued twenty-five advisory opinions. The opinions are regarded as advisory and thus non-binding 84 but there is no doubt that they are regarded as authoritative on the legal issues addressed. In its advisory opinions, the Court has not been hesitant to wade into legal issues even if they are surrounded by a highly charged political context such

75 U.N. Dept. Public Info., News And Media Division, Oct. 8, 2008, available at http://www.un.org/news/press/docs/2008/ga10764.doc.htm(last visited on Oct. 8, 2008).

76 Id.

77 Id.

78 Id.

79 Id.

80 Id.

81 Id.

82 Id.

83 Id.

84 U.N. Charter. art. 96(1). 
as the Western Sahara opinion in 197585 and the Construction of a Wall opinion in 2004.86

A self-determination and a secession issue has also been raised in the Georgia $v$. Russian Federation Case. ${ }^{87}$ Georgia has claimed that Russia has violated the International Convention on the Elimination of All Forms of Racial Discrimination (CERD) 88 by its treatment of ethnic Georgians within the enclaves of South Ossetia and Abkhazia. Georgia asserts that Russia's actions have "the effect of denying the right of selfdetermination to the ethnic Georgians remaining in South Ossetia and Abkhazia...."89 Georgia also accuses Russia of undermining her sovereignty by recognizing the independence of the enclaves and has asked the Court to order Russia "not to recognize in any manner whatsoever the de facto South Ossetian and Abkhaz separatist authorities...."90 The Court issued interim measures of protection on October 15, 2008, but simply ordered both parties to refrain from acts of racial discrimination within the enclaves, not to impeded humanitarian assistance in support of rights under CERD, and not to aggravate the dispute. Because the Court's jurisdiction is founded on article 22 of CERD, the article by which parties to CERD grant jurisdiction to the Court to settle disputes arising under the Convention, it is unlikely that the Court will address the selfdetermination or secession issues unless they find them inextricable from issues relating to racial discrimination.

One overall problem on legal pronouncements about the legality of secession/independence of a particular area from a larger territorial entity is that the context is bound to be very fact specific, particularly in the case of Kosovo where there have been many U.N. Security Council resolutions relating to the area. 91

Of course, all legal disputes arise in a particular context, and many, such as territorial disputes, are exhaustingly fact specific. ${ }^{92}$ Nonetheless, the Court manages to decide cases relating to such disputes. An advisory opinion by the Court containing a general discussion of the legal dimensions of secession/independence with a particular focus on Kosovo would do much to concretize this elusive area of international law.

85 Western Sahara, Advisory Opinion, 1975 I.C.J. 12 (Oct.16).

86 Legal Consequences of the Construction of a Wall in the Occupied Palestinian Territory, Advisory Opinion, 2004 I.C.J. 136 (Jul. 9).

87 Application of the International Convention on the Elimination of All Forms of Racial Discrimination (Georgia v. Russian Federation) 2008 I.C.J. (Order for provisional measures, Oct. 15, 2005).

88 Adopted Dec. 21, 1965, 660 U.N.T.S. 195, entered into force Jan. 4, 1969.

89 Georgia v. Russian Federation, supra note 87, at 13.

$90 \quad$ Id. at 22 .

91 See e.g. S.C. Res. 1244; U.N. Doc. S/RES/1244 (June 10, 1999).

92 See Sovereignty Over Pedra Branca/Pulau Batu Puteh, Middle Rocks and South Ledge (Malaysia v. Singapore), 2008 I.C.J. (May 23, 2008). 


\section{The European Standards for State Recognition After Secession}

As Yugoslavia started to crumble in the early 1990s, Europe established a mechanism for recognition of new states in 1991 known by its chairman's name as The Badinter Commission.93 Although the mandate of the Commission was vague in the early days of its operation, it soon became clear that its geographic scope included all of the former Yugoslavia and that it could address a wide variety of issues including: "Minority rights, use of force, border changes, the rule of law, state sucession, and recognition...."94 Ultimately, the Commission issued fifteen opinions, a number of which addressed whether a constituent republic of the former Yugoslavia should be recognized as a new state. The European Community had issued Guidelines on the Recognition of New States in Eastern Europe and the Soviet Union 95 and the Commission sought to apply the Guidelines when several of the Yugoslav republics filed applications for recognition.

The Guidelines set out standards to be met by applicants before recognition was to be accorded. They confirmed the Community's "attachment to the principles of the Helsinki Final Act and the Charter of Paris, in particular the principle of selfdetermination." The applicant entity was to be constituted "on a democratic basis," "accept... international obligations" and commit to "a peaceful process and to negotiations." It must also accept the U.N. Charter, "rule of law, democracy and human rights," "guarantees for the rights of ethnic and national groups and minorities," "the inviolability of all frontiers which [could] only be changed by peaceful means and by common agreements," "disarmament and nuclear non-proliferation," and agree to settle by "arbitration, all questions concerning State sucession." Entities that come about as a result of aggression would not be recognized, and an applicant had to guarantee that it had "no territorial claims towards a neighboring Community State."96

Slovenia applied for recognition and the Commission found the Guidelines' criteria had been met. 97 The member states of the EC promptly recognized Slovenia. When Croatia sought recognition, fighting was still occurring on its territory. The Commission was concerned about the recognition of minorities. The opinion admitted that Croatia

\footnotetext{
93 Declaration of European Community Foreign Ministers on Yugoslavia, Brussels (Aug. 27, 1991).

94 Thomas D. Grant, The Recognition of States, 156 (1999) (footnotes omitted).

95 EC Guidelines, 31 I.L.M. 1486 (1992).

96 Id.

97 Arbitration Commission, Opinion No. 7, 11 Jan. 1977; 92 I.L.R. 188.
} 
was still not meeting certain obligations but "nevertheless satisfies the requirements of international law regarding the protection of minorities...."98

The Commission also found that Macedonia had met the requirements of the Guidelines.99 Greece had raised concerns over Macedonia's territorial aspirations to part of Greece but Macedonia clearly renounced all such claims. Bosnia Herzegovina's recognition proved problematic and the Commission did not think that the "will of the peoples of Bosnia-Herzegovina to constitute the SRBH as a sovereign and independent State [could] be held to have been fully established."100 In light of a later referendum in which a majority of the electorate voted for independence, the Community recognized Bosnia-Herzegovina's independence in April, 1992.

Serbia-Montenegro claimed to be the successor state to the former Yugoslavia but the U.N. would not allow Serbia-Montenegro to take Yugoslavia's seat and it was not admitted to the U.N. in its own right until 2000. The Commission had earlier taken the same view and determined "that the SFRY no longer exists"101 so that SerbiaMontenegro could not be regarded as the successor to the sate of Yugoslavia.

The Guidelines and the Opinions of the Badinter Comission moved the European Union towards a process of collective recognition and created a quasi-judicial mechanism for resolving issues of status even though European member states' recognition practice did not always follow the Commission's decisions. 102 Widespread recognition certainly "can resolve uncertainties as to status" and "where recognition is general, it may be practically conclusive."103 A collective recognition practice by a group of neighboring states when an entity is seceding from a larger territorial unit obviously moves the new entity closer to full acceptance as a sovereign and independent state and endorses the legitimacy of secession in the particular circumstances.

The break up of the Soviet Union took a somewhat different path. There was little opposition to Russia's claim to be the successor state to the USSR and Russia rapidly recognized the independence of the three Baltic states and the other twelve constituent republics and, by May 1992, they were all admitted to the U.N. as independent states.104

\footnotetext{
98 Arbitration Commission, Observations on Croatian Constitutional Law, 4 July 1992, 92 I.L.R. 209, 211.

99 Arbitration Commission, Opinion No. 6, 11 Jan.1992; 92 I.L.R. 182, 187.

100 Arbitration Commission, Opinion No. 4, 11 Jan. 1992: 92 I.L.R. 173, 178.

101 Arbitration Commission, Opinion No. 8, 4 July 1992; 92 I.L.R. 199, 201, 202.

102 Thomas D. Grant, The Recognition of States 164-166 (1999).

103 Crawford, supra note 2, at 27.

104 Id. at 393-395.
} 


\section{Is There a Right of Autonomy within a Greater Territorial Unit for Peoples?}

\section{A. The Amorphous Nature of Autonomy}

Although there has been a world wide campaign to "Free Tibet"105 that has as its goal ending "the Chinese occupation of Tibet" and declares "the right of the Tibetans to determine their own future," the Dalai Lama, who is widely regarded as the spiritual leader of Tibet, has recently insisted that he is only seeking wider measures of autonomy for Tibet,106 within China, rather than independence. It is unclear whether the Dalai Lama's view is consistent with the general population of Tibet.107 Some Tibetans would "like to go further than the conciliatory 'middle way' approach of the Dalai Lama...." 108

The term "autonomy" has no generally accepted definition. As Professors Hannum and Lillich noted in their early study of twenty-two cases of non-sovereign entities: "It must be remembered that autonomy is not a term of art or a concept that has a generally accepted definition in international law."109 Claims for more autonomy generally mean that the region or persons making the claim want greater authority to make final decisions on a wider variety of topics without the interference or veto power of the central government, but there is no agreement on which topics are properly within the scope of autonomy. Issues on which autonomy is claimed range from fiscal power, to taxation, to control of natural resources and even reach topics such as foreign policy, security and defense.

The question then arises whether, in international law, there is any right for peoples to claim autonomy, whatever the word may encompass. At the present time, the answer to that question seems to be a rather resounding "No." The Association of the Bar of the City of New York in its comprehensive report on The Separatist Crisis in Moldova stated: "Under international law there is no 'right' to fiscal or governmental

105 The Campaign's website is available at: www.freetibet.org (last visited on Oct. 1, 2008).

106 http://nesxinhuanet.com/english/2008-03/31/content_7889662.htm; Amanda Bower, Dalai Lama: Tibet Wants Autonomy, Not Independence, TIME, Apr. 16, 2006, available at http://www. dalailama.com/news.42.htm.

107 Krittivas Mukherjee, Dalai Lama Calls Special Meeting to Discuss Tibet, REuTERs, Sept. 12, 2008, available at http://www.reuters.com/aritcle/worldNews/idUSDEL35397720080912(last visited on Oct. 1, 2008).

108 Id.

109 Hurst Hannum \& Richard Lillich, The Concept of Autonomy in International Law, 74 AM. J. INT'L L. 858, 885 (1980). 
autonomy within a state."110 The report concluded that: "[A]ny supposed 'right' to autonomy... becomes largely an issue of domestic law."111 Others have concluded that autonomy is simply an internal political decision. 112

\section{B. Is There an Obligation for States to Facilitate Autonomy for Minority Groups?}

Professor Geoff Gilbert's recent article asks: "whether there is an obligation on States in international law to facilitate autonomy for minority groups as part of the right to selfdetermination or even as part of some wider conception of minority rights."113 He describes "participatory, cultural and financial autonomy"114 as the "means of providing for the right to self-determination of non-colonial peoples and the rights of minorities within the State structure."115 By examining many of the major human rights treaties and other relevant documents he concludes that: "autonomy for all groups within the State can be justified under existing international instruments...."116 From this he does not conclude that there is a right to autonomy for minority groups but only that "a principled right to autonomy would provide in practical terms appropriate rights for all groups within the State, bridging the gap between the self-determination of peoples and minority rights."117 In other words, he believes that presenting the only choices as either secession/independence or remaining simply as minorities within a larger state is a false dilemma. He offers the solution of varying degrees and types of autonomy which will necessarily be "case specific"118 and must be "appropriate to the needs of the group."119 By linking a people's right to self-determination with rights of minorities to be found in many human rights documents, Gilbert provides a varying autonomy bridge between secession and groups remaining entirely subject to the larger state. What Gilbert's solution gains from innovative thinking it loses in its indeterminacy at the present time. This is not to reject the solution outright, for all rights start out as indeterminate wishes and must move along the road to determinacy, if at

110 Thawing a Frozen Conflict: Legal Aspects of the Separatist Crisis in Moldova, Special Committee on European Affairs, Mission to Moldova, Assn. of the Bar of the City of N.Y., at 28.

111 Id. at 29.

112 Martti Koskenniemi, National Self-Determination Today: Problems of Legal Theory and Practice, 43 INT'L \& CoMP. L.Q. 241, 269 (1994).

113 Geoff Gilbert, Autonomy and Minority Groups: A Right in International Law, 35 CORNELL INT'L L.J. 307, 309 (2002).

114 Id. at 352 .

115 Id.

116 Id. at 353.

117 Id.

118 Id.

119 Id. at 352. 
all, as the international community decides to support them.

Alternatively, the concept of "internal self-determination"120 as used by the Supreme Court of Canada in the Secession of Quebec Case,121 could be fleshed out as a means of providing greater autonomy within the existing state framework. Professor Robert Sloane aptly points out that since the 1990s, with the break up of the Soviet Union, the former Yugoslavia and Czechoslovakia and the emergence of new states in the wake of those dissolutions, the question has arisen: "whether and, if so, under what conditions, the right to self-determination requires that States offer greater autonomy...to disaffected national, ethnic, or other minorities."122

A number of authors have suggested that a preferred model for Iraq, when it emerges from foreign occupation, would be either three independent states or a federal state with three largely autonomous regions roughly defined by ethnic and religious divisions. 123 The autonomy model would certainly equate with the Canadian Supreme Court's notion of "internal self-determination" but may not satisfy the Kurdish population which has long sought an independent Kurdish state.

Some of the scholarship on indigenous peoples' right to self-determination has also focused on autonomy. Professor Shin Imai, in his forthcoming paper, Indigenous SelfDetermination and the State 124 examines models of autonomy for indigenous peoples in Canada, the U.S., Australia and New Zealand and assesses their chances of success. Perhaps by linking a peoples' right to self-determination with minority rights protected by a variety of human rights documents and combining that with models for autonomy learned from indigenous peoples' experience, the Tibetans may find a way forward from their present status with China.

\section{Autonomy for Tibet Within the Framework of Chinese Law and Practice}

Of course, the Chinese Constitution and several laws have various provisions addressing regional autonomy, minority affairs and regulation of religion and language, all of which could result in considerable levels of autonomy for Tibet and other regions.

120 Supra note 31

121 Id.

122 Robert Sloane, The Policies of State Succession: Harmonizing Self-Determination and Global Order in the Twenty-First Century, 30 FordHAM INT'L L.J. 1288, 1306 (2007).

123 Peter W. Galbraith, How to Get Out of Iraq, 15 N.Y. Review Books, at 42, May 13, 2004; Joseph R. Biden \& Leslie H. Gelb, Unity Through Autonomy in Iraq, N.Y. TIMEs, May 1, 2006, at A19.

124 Forthcoming in Peer Zumbansen, John W. Cioffi \& Lindsay Kraussindigenous eds., Peoples and the LaW: COMPARATIVE AND CRITICAL PERSPECTIVEs (2009), available at http://ssrn.com/abstratct=1262780 (last visited on Oct. 8, 2008). 
As yet, however, China is still in the process of deciding what role law and legal institutions will play in her rapidly developing economy and her rising global dominance.

Section 6 of Chapter III of Peoples Republic of China's (PRC's) Constitution125 addresses governance in autonomous regions including Tibet. Articles 112 through 122 create organs of self-government in autonomous areas, give preference to minority nationality representation within these organs, confer some local powers to local organs of state to enact local regulations, to administer the finances of the autonomous areas, to administer local economic development, to administer educational, scientific, cultural, public health and "physical culture" affairs, to organize local public security forces for the maintenance of public order, and to employ commonly uses spoken and written languages of the area. Section 6 also states that the autonomous areas accept financial, material and technical assistance from the state to accelerate minority economic and cultural development. Such a broad range of granted powers to the autonomous regions might be expected to herald flourishing autonomous governance in regions such as Tibet. In practice, however, this is far from the case.

Studies of how this delegated regional power works in practice tend to find that the provisions aim "to divide local non-Han minorities by promoting political competition that weakens factors of commonality...."126 Because of the power of the central Chinese Communist Party, "local minority administrative leaders are often perceived as impotent followers of the Han-dominated CCP. Indeed, authoritative government directives confirm that the Party considers itself the final arbiter of minority nationality interests." 127 Even in the management of local financial matters decisions are subject to overall central government policy.

Article 120 makes it clear that the central government retains power related to security issues as was made very clear by the harsh crack down on monks protesting in Tibet in the spring of 2008. Use of minority languages in government business remain marginalized despite the encouraging language of Article 121.

Article 4 of the Constitution prohibits "[d]iscrimination against and oppression of any nationality" but also states that "any acts that undermine the unity of nationalities or instigate their secession are prohibited." All nationalities are considered protected by this article, including the Han. The result has been that "anti-Han sentiment in minority areas"128 has been prohibited. Article 4 also makes it clear that secession is never an

125 PRC Cons. Ch. II, §6, arts. 112-122 (1982).

126 Pitman Potter, Governance of China's Periphery: Balancing Local Autonomy and National Unity, 19 CoLUM. J. ASIAN L. 293, 299 (2005).

127 Id.

128 Id. at 304. 
option for autonomous areas by the very direct language against actions that instigate secession and by the statement that: "All national autonomous areas are inalienable parts of China."

A major piece of Chinese legislation, the Regional Ethnic Autonomy Law (REAL), initially enacted in 1984 and since amended,129 might have strengthened the role of the autonomous regions but assessment of its effect has been quite to the contrary. One scholar reports that: "The underlying principles of the [REAL] underscore the dominance of central control....the law works to diminish the very ideal [autonomy] it is intended to celebrate." 130

The special legislative approach to Hong Kong and Macao as Special Administrative Regions (SARs), which has also been proposed for Taiwan if re-unification ever occurs, also holds potential for a more autonomous model. All of these special legislative grants are, however, subject to central government policy amendments. There are a number of historic, financial and economic reasons why the Chinese government is currently prepared to keep the "One Country, Two Systems" approach in place for the designated areas but there is no broad based confidence, either within China or outside, that the SARs will continue over time and far less confidence that the model will be extended to other areas, such as Tibet.

Constitutional provisions, legislative enactments, or special arrangements currently in place for certain areas seems unlikely to produce any level of autonomy with teeth for Tibet in the near future.

\section{Application of International Law Standards to Tibet}

\section{A. Competing Views of the Relationship of Tibet and China}

"Beauty" we know is in the eye of the beholder. History often has the same qualities of subjectivity. For some scholars, Tibet has always be part of China. For other scholars, Tibet has generally operated as an independent country and was invaded and occupied by the Chinese starting in 1949 and continuing since 1951.131 Both sides marshall a variety of sources in support of their view. Given that Tibet has definitely not operated

129 Regional Ethnic Autonomy Law, in force Oct. 1, 1984, revised Feb. 28, 2001, available at http://www.cecc.gov/pages.roundtables/041105.index.php (last visited on Oct. 1, 2008). See generally SoNG Caifa (ed.), General Survey on the Law on Autonomy in Minority Areas (2003).

130 Potter, supra note 126 , at 307.

131 For one website that cogently relates both "The Chinese History of Tibet" and "The Tibetan History of Tibet" 
as an independent country over the last half century, it may not be profitable, for the purposes of this article, to sift through the voluminous evidence produced by the competing views, although there is no doubt that concluding that Tibet was independent prior to the Chinese assertion of power from 1951, would bolster Tibet's claim to independence.

\section{B. Are the Tibetans a People to Whom the Right of Self- Determination Would Attach?}

The Tibetans are ethnically distinct from the overwhelming majority of Chinese Han citizens. Han Chinese make up over ninety per cent of the inhabitants of China. Tibetans also share an historically distinct territorial location, and they share a distinct language, culture and religion. The term "peoples," when referring to "the selfdetermination of peoples," as used in the U.N. Charter and the two principal human rights convenants132 springing from the Universal Declaration of Human Rights, 133 has received relatively little scholarly attention. The UNESCO Report on the concept of the rights of peoples recognized that "peoples' rights are not State's rights."134 Peoples are variously described as "minorities,"135 "indigenous people,"136 people possessing "cultural, religious, linguistic, racial or other forms of identity."137 In the Report, peoples are described as:

1. a group of individual human beings who enjoy some or all of the following common features:
(a) a common historical traditions;
(b) racial or ethnic identity;
(c) cultural homogeneity;
(d) linguistic unity;
(e) religious or ideological affinity;
(f) territorial connection;
(g) common economic life.

2. the group must be of a certain number which need not be large (e.g. the people of go to: http://www.rangzen.com/history/views.htm (last visited on Aug. 20, 2008).

132 See supra text accompanying notes $23 \& 24$.

133 G.A. Res. 217A, U.N. GAOR, 3d Sess., pt. I (Dec. 10, 1948).

134 Final Report and Recommendations, UNESCO International Meeting of Experts on Further Study of the Concept of the Rights of Peoples, SHS-89/CONF. 602/7 at 2 (Feb. 22, 1990).

135 Id. at 4.

136 Id.

137 Id. at 6. 
micro States) but which must be more than a mere association of individuals within at State;

3. the group as a whole must have the will to be indentified as a people or the consciousness of being a people - allowing that groups or some members of such groups, though sharing the foregoing characteristics, may not have that will or consciousness; and possibly;

4. the group must have institutions or other means of expressing its common characteristics and will for identity. 138

Current legal scholarship seems clearly weighted towards recognizing the term "peoples" as capable of referring to a sub-group of the larger body of inhabitants of a state. There can be little doubt that the Tibetans are a "people" as that term is used in international law, even if they are viewed as a sub-group living within China. As a "people" then, the Tibetans certainly have the right to self-determination and may indeed have other rights as a minority group.139 We return then, once again, to the question of what rights "self-determination" confers on people and whether it ever condones secession.

\section{What Legal Principles Can We Deduce from the Fact that Secession Happens?}

This article has already noted the wise discussion of law's "effectivity principle" as articulated by the Canadian Supreme Court.140 This principle recognizes that law accommodates to reality even if the reality occurred through illegal or extra-legal means. Law grants legality to an acquired sovereign status even if it does not retroactively grant legality to the method of acquisition of sovereignty.

Secession happens. If we look at a number of actual secessions, we may be able to recognize some common characteristics that accompany such events. Such characteristics may indicate whether it is more likely, or less likely, that an entity, such as Tibet, could engage in a successful secession and ultimate recognition as a sovereign state by the international community of states.

138 Id. at 7-8. See also James Crawford (ed.), The Rights of Peoples (1988).

139 See supra text accompanying notes $25-27$.

140 See supra text accompanying notes $39 \& 40$. 


\section{Judging the Legitimacy and Likelihood of Success of Claims to Secession}

Once part of a larger territorial state has enunciated a claim to secession, the scholarly literature focuses on methods for calibrating the legitimacy of such claims. Professor Frederic Kirgis found two crucial factors: "the degree of representative government...and the extent of destabilization that the international community will tolerate...."141 From this he concludes that claims to secede from broadly representative democracies are not likely to be seen as legitimate but "a claim to secede from a repressive dictatorship may be regarded as legitimate."142 This type of claim may be supported even if it is thought that the claim will have a seriously destabilizing effect in the area. 143

Crawford, after a careful study of many historic examples of secession concludes that:

in the pre-1945 period it was always considered possible for a group to separate from a State and to achieve independence by achieving secure control over its territory --if necessary, by wining a war of independence. Secession of this kind was a process that could take years and which might or might not lead to a successful outcome. 144

Similarly, over time, there was "acceptance of self-determination leading to the independence of colonial territories...."145 Nonetheless, Crawford notes that: "Since 1945 the international community has been extremely reluctant to accept unilateral secession of parts of independent States if the secession is opposed by the government of that State. In such cases the principle of territorial integrity has been a significant limitation."146 Writing in 2006, Crawford determined that: "Since 1945 no State which has been created by unilateral secession [which he later distinguished from "outright dissolution of the predecessor state"] has been admitted to the United Nations against the declared wishes of the government of the predecessor State."147 We are still awaiting the final consequences of Kosovo's declaration of independence from Serbia on February 17, 2008, against Serbia's wishes, but that case is complicated by NATO's 1999 invasion of the former Yugoslavia on behalf of the Kosovar/Albanian population

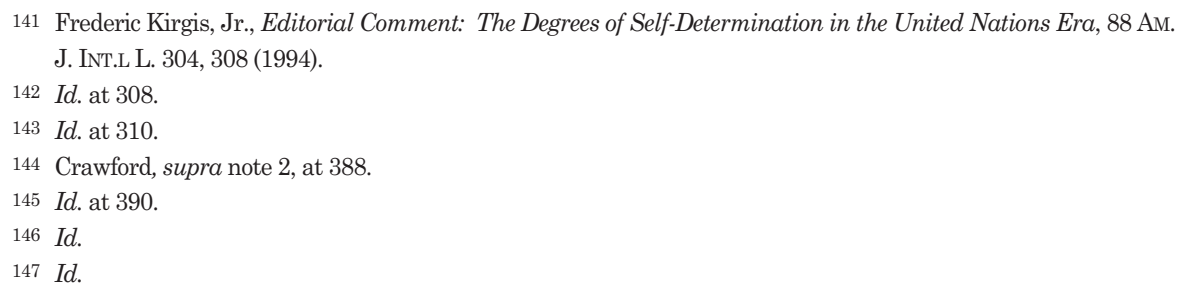


and the dissolution of the former Yugoslavia. The other factor that militates against a successful outcome for any Tibetan unilateral claim to independence is the military might of China, the adamancy with which China asserts that Tibet must remain part of China, and the lack of an organized armed Tibetan resistance movement. What works in favor of Tibet's claims to independence is her perceived quasi-colonial status, the lack of a representative form of government in China (for anyone, not just the Tibetans) and the widely held belief of violations of human rights by the Chinese against the Tibetans. At the present time Tibet only has a tenuous claim to the right to secession even if the argument that self-determination can, in certain circumstances, include the right to secession (itself a tenuous argument.) A claim to autonomy, however, though without a settled meaning and still possessing a variety of indeterminate facets, may be successful if the question is viewed by refocusing on minorities' rights and models for autonomy. Perhaps the Dalai Lama is wise in only asking for a greater measure of autonomy at this time.

\section{Conclusion}

A careful examination of the law surrounding a peoples' right to self-determination leads to the conclusion that the Tibetans are a "people" and that they have a right to self-determination. The right to self-determination, however, does not yet confirm a right to secession except in the limited circumstances of a colonially administered people, a people under foreign occupation, or a people suffering widespread violations of human rights because of their distinct qualities. Some readings of history would put Tibet in one, or more, of the above categories. If we look at the practicalities on the ground for the chances of a successful Tibetan secession from China, however, such a scenario seems extremely unlikely.

China has an array of laws addressing issues of autonomy for minority nationalities as well as examples of Special Administrative Regions. At the moment, those laws are not being used to confer any real power on the regional governments and there seems little possibility that new SARs will be created, other than for Taiwan in the event of reunification. Nonetheless, the laws and models are in place and could be used to grant greater powers in the future if the central government can be persuaded that such is in the best interests of China as a whole.

Although autonomy has no defined meaning in international law and cannot yet be declared to be a right attaching to specific sub-groups within a larger territorial unit, creative combining of the self-determination of peoples with various human rights 
242 Valerie Epps

attaching to minority groups, together with observing the types and dimensions of autonomy granted to indigenous persons in various parts of the world, may result in a viable route forward for the Tibetan people within the greater territorial unit of China. 